\title{
ASSESSMENT OF INTRACANAL MEDICATIONS CYTOTOXICITY ON L929 FIBROBLAST CELLS
}

\author{
AVALIAÇÃO DA CITOTOXICIDADE DE MEDICAMENTOS INTRACANAIS \\ EM FIBROBLASTOS L929
}

\author{
Michelle de Paula FARIAS ${ }^{1}$; Felipe de Souza MATOS $^{1}$; Nayane Chagas CARVALHO' ${ }^{1}$; \\ Roque Pacheco de ALMEIDA ${ }^{2}$; Adriano Augusto Melo de MENDONÇA ${ }^{3}$; \\ Ricardo Luiz Cavalcanti de ALBUQUERQUE JÚNIOR ${ }^{4}$; Maria Amália Gonzaga RIBEIRO ${ }^{3}$ \\ 1. Postgraduate Program in Dentistry, Federal University of Sergipe, Aracaju, SE, Brazil. felipe_smatos@ hotmail.com; 2. Associate \\ Professor, Department of Medicine, Federal University of Sergipe, Aracaju, SE, Brazil; 3. Adjunct Professor, Department of Dentistry, \\ Federal University of Sergipe, Aracaju, SE, Brazil; 4. Titular Professor, Department of Dentistry, Tiradentes University, Aracaju, SE, \\ Brazil
}

\begin{abstract}
This study aimed to evaluate the cytotoxicity of intracanal medications on L929 fibroblast cells at different periods of observation. The following experimental groups were studied: calcium hydroxide with camphorated paramonochlorophenol and glycerin (CPG); iodoform with glycerin (IG); calcium hydroxide with iodoform and distilled water (CIW); iodoform with distilled water (IW); calcium hydroxide with distilled water (CW); Otosporin ${ }^{\circledR}$ (OT); and a control group composed of cells and culture medium. Eluates were prepared from each group and placed in contact with 1 x $10^{5}$ cells/well for periods of 30 minutes, 12, 24, 48 and 72 hours, 5 and 7 days. After each experimental period, a cytotoxicity test was performed using methyltetrazolium (MTT) and a spectrophotometer at an optical density of $570 \mathrm{~nm}$ to analyze cell viability. The ANOVA and Tukey test with a significance level of $5 \%$ was used to analyze the data. At 30 minutes and at 12 hours, all groups were equal to the control group. At 24 hours, there was greater cytotoxicity in the IG group than in the control group $(\mathrm{P}<0.001)$. At 48 hours, only the OT group was cytotoxic $(\mathrm{P}<0.001)$. At 72 hours and at 5 days, the most cytotoxic groups were CW and OT. At 7 days, the IW and CPG groups were the least cytotoxic (P <0.001). With respect to experimental time, significant differences between 24 hours and 7 days were observed in all groups. Otosporin ${ }^{\circledR}$ was the most cytotoxic medication, followed by calcium hydroxide with distilled water.
\end{abstract}

KEYWORDS: Cytotoxicity tests. Immunologic. Endodontics. Calcium hydroxide. Iodoform. Fibroblasts.

\section{INTRODUCTION}

Intracanal medications play important roles in endodontic therapy, including elimination of microorganisms that survive biomechanical preparation (LANA et al., 2009), endotoxin neutralization, prevention of microorganism entry from saliva, reduction of pain, modulation of periradicular inflammation and stimulation of repair by mineralized tissue (KANDASWAMY et al., 2010; HEWARD; SEDGLEY, 2011).

Periapical tissue must be biocompatible with the degradation products of the medications, as they will be in close contact to periradicular tissue (HEWARD; SEDGLEY, 2011). Otherwise these products can cause high levels of inflammation, mediated by a number of factors including histamines, kinins, and neuropeptides, which can induce tissue destruction and slow the cicatricial process (YOSHINO et al., 2013). Therefore, these drugs should possess the ability to induce repair in the injured area without interfering with osteogenesis and cementogenesis (CAMARGO et al., 2009; SILVA et al., 2012A).
Calcium hydroxide is alkaline, antimicrobial and can induce tissue mineralization (HOLLAND et al., 1999). When calcium hydroxide comes into direct contact with subcutaneous tissue, inflammation occurs (MATOS et al., 2014), inducing moderate to severe levels of protein denaturation in cells, especially neutrophils; areas of necrosis and dystrophic calcification are also observed.

Over time, calcium hydroxide can induce moderate angioblastic proliferation with fibrous tissue capsules and moderate amounts of collagen fibers (NELSON FILHO et al., 1999; TOMAZ et al., 2013). However, calcium hydroxide is considered to be less cytotoxic than other medications commonly used in endodontic therapy (GUIGAND et al., 1999; SEPET et al., 2009; MIURA et al., 2010; MATOS et al., 2014).

Iodoform has a high iodine content, which gives it a strong antimicrobial activity (CWIKLA et al., 2005), and iodoform is better at reducing the duration of inflammation compared to other intracanal medications. When placed in subcutaneous tissue, iodoform produces a small area of necrosis that is restricted to the wound area and 
surrounded by inflammatory infiltrates of mild intensity, primarily macrophages (PALLOTTA et al., 2010). In cell-based studies, iodoform has not been genotoxic (HUANG et al., 2009).

Otosporin $^{\circledR}$ is a combination of hydrocortisone, neomycin sulfate and polymyxin B and has anti-inflammatory, immunosuppressive, vasoconstrictor and antimicrobial properties. It is commercially available in aqueous suspension, in white color, with easy handling, insertion and removal of the root canal (ESTRELA et al., 2005; TOMAZ et al., 2013).

Camphorated paramonochlorophenol (CPMC) is a temporary dressing that is typically used as a vehicle in intracanal medications. Its cytotoxicity has been shown to be reduced when administered in combination with calcium hydroxide (CPG) (GRECCA et al., 2001; ANTHONY et al., 2005; GAHYVA; SIQUEIRA JUNIOR, 2005). CPMC has no genotoxic or mutagenic effects on cells (CHANG et al., 1998; HUANG et al., 2009).

The association of intracanal medications can improve their efficacy by enhancing its effects on tissues. The vehicle used to form the endodontic pastes affects the physical and chemical properties of intracanal medications and thus, its clinical application. In general, viscous and oily vehicles prolong the antibacterial action of the medications compared to aqueous vehicles (ESTRELA; PESCE, 1996).

Despite research showing that some intracanal medications are cytotoxic to tissues, there is not much scientific data related to this topic in the literature. Therefore, this study aimed to evaluate the cytotoxic effects of intracanal medications, including calcium hydroxide, iodoform, Otosporin ${ }^{\circledR}$ and their combinations during various observation times on L929 fibroblast cells.

\section{MATERIAL AND METHODS}

\section{Preparation of eluates}

The intracanal medications used for the cytotoxicity assays in this study were calcium hydroxide (Biodynamics Chemicals \& Pharmaceuticals LTDA ${ }^{\circledR}$, PR, Brazil), iodoform (Kdent $^{\circledR}$, Quimidrol, SC, Brazil) and Otosporin ${ }^{\circledR}$ (Farmoquímica S/A ${ }^{\circledR}$, RJ, Brazil). The vehicles selected were distilled water, glycerin (Single Pharmacy $^{\circledR}$, Aracaju, SE, Brazil) and camphorated paramonochlorophenol (Biodynamics Chemicals \& Pharmaceuticals LTDA $^{\circledR}, \quad$ PR, Brazil). The combinations of medications and the proportion of each drug are described in Table 1.

Table 1. Description of groups and dosages of intracanal medications.

\begin{tabular}{ccc}
\hline Groups & Components & Dosages \\
\hline \multirow{2}{*}{ CPG } & Calcium hydroxide & $1 \mathrm{~g}$ \\
& Camphorated paramonochlorophenol & $100 \mu \mathrm{L}$ \\
IG & Glycerin & $1.2 \mathrm{~mL}$ \\
& Iodoform & $1.5 \mathrm{~g}$ \\
$\mathrm{CW}$ & Glycerin & $600 \mu \mathrm{L}$ \\
& Calcium hydroxide & $1 \mathrm{~g}$ \\
$\mathrm{CIW}$ & Distilled water & $1.1 \mathrm{~mL}$ \\
& Calcium hydroxide & $1.5 \mathrm{~g}$ \\
$\mathrm{IW}$ & Iodoform & $1.5 \mathrm{~g}$ \\
$\mathrm{OT}$ & Distilled water & $1.75 \mathrm{~mL}$ \\
Control & Iodoform & $1.5 \mathrm{~g}$ \\
& Distilled water & $600 \mu \mathrm{L}$ \\
& Otosporin & $40 \mu \mathrm{L}$ \\
& Culture medium & $100 \mu \mathrm{L}$ \\
\hline
\end{tabular}

The intracanal medicaments in powder form were used at the dosages described in Table 1. The specimens were prepared into pastes using sterile polyethylene tubes with diameters of $5 \mathrm{~mm}$ by $2 \mathrm{~mm}$ depth. Otosporin ${ }^{\circledR}$ was a liquid, so it was stored in $2 \mathrm{~mL}$ sterile Eppendorf tubes for 24 hours. After this period, the medications were sterilized with ultraviolet light for 1 hour to avoid contamination. For each group, three specimens were prepared and placed at the bottom of a 24 -well culture plate.

Then, $2 \mathrm{~mL}$ of RPMI 1640 culture medium with L-glutamine (Gibco, Life Technologies Co. ${ }^{\circledR}$, Carlsbad, CA, USA) without fetal bovine serum (Sigma Chemical Co. ${ }^{\circledR}$, St. Louis, MO, USA) or antibiotics was placed in the wells and incubated at $37^{\circ} \mathrm{C}$ with a $100 \%$ humidified atmosphere of $5 \%$ $\mathrm{CO}_{2}$ for 24 hours (Incubator $\mathrm{CO}_{2}$, Sanyo Electric Co. Scientific Ltd. ${ }^{\circledR}$ MCO-17AC, Japan). The 
incubation period ensured that the active products of the intracanal medications could be diffused into the culture medium, producing eluates of each intracanal medication (CAMARGO et al., 2010). For each group, three eluates were produced, even for the control group.

\section{Cell culture}

The protocol for cytotoxicity analysis was based on ISO 10993-5, which allows for simplicity of implementation, speed, accuracy and the ability to be reproduced (MOSMANN, 1983; SILVA et al., 2012B). This study used murine L929 fibroblast cells obtained from the cell bank of the Laboratory of Molecular Biology, Department of Pathology, University Hospital Professor João Cardoso Nascimento Júnior, Federal University of Sergipe. These cells exhibit a high degree of stability, ease of manipulation and cultivation, and high rates of proliferation without alterations in cell phenotype (YASUDA et al., 2010). Furthermore, cells from humans and mice exhibit no differences in responses between them (KANDASWAMY et al., 2010).

The fibroblasts were thawed, placed in 25 $\mathrm{cm}^{2}$ culture flasks (Greiner Bio-One ${ }^{\circledR}$, Americana, São Paulo, Brazil), cultured in RPMI 1640 culture medium (containing L-glutamine, $10 \%$ fetal bovine serum, $1 \%$ penicillin $(10000 \mathrm{UI} / \mathrm{mL}))$, and maintained at $37^{\circ} \mathrm{C}$ in a humidified incubator containing $5 \% \mathrm{CO}_{2}$. Confluent cells were detached from the culture flask with $0.25 \%$ trypsin and $0.05 \%$ ethylenediaminetetraacetic acid (Gibco, Life Technologies $\mathrm{Co}^{\circledR}$, Carlsbad, CA., USA) for 5 minutes. Aliquots were subcultured into larger flasks for three passages to produce the optimal number of cells for the experiment (SILVA et al., 2013). The cells were deposited into 96-well plates $\left(\right.$ Prolab $^{\circledR}$, São Paulo, SP, Brazil) at a concentration of $1 \times 10^{5}$ cells/well ${ }^{-1}$ and incubated for 24 hours (SILVA et al., 2013). Next, $100 \mu 1$ of each eluate was placed into the wells, and the culture plate was placed in the incubator for experimental periods of 30 minutes, 12 hours, 24 hours, 48 hours, 72 hours, 5 days and 7 days.

After each experimental period, the cytotoxicity was analyzed using $20 \mu \mathrm{l} /$ well MTT solution $\left(\right.$ Sigma $^{\circledR}$, St. Louis, MO, USA) at a concentration of $5 \mathrm{mg} / \mathrm{mL}$ for 4 hours (YOSHINO et al., 2013). The formazan that formed during this period was dissolved by adding $100 \mathrm{~mL}$ of acidified isopropanol solution with $0.04 \mathrm{M} / \mathrm{HCl}$ to each well and shaking the culture plate for 30 minutes (GOMES-FILHO et al., 2009). The culture plates were read using a microplate spectrophotometer (Microplate Spectrophotometer - Epoch ${ }^{\mathrm{TM}}$, BioTek Instruments ${ }^{\circledR}$, Inc., Winooski, Vermont, USA) at a wavelength of $570 \mathrm{~nm}$; the results were expressed as absorbance values proportional to the intensity of coloration in each well.

\section{Statistical analysis}

Assays were performed in triplicate throughout this study. The data were subjected to Analysis of Variance (ANOVA) of two factors, i.e., "temporary dressing" and "assessment period" and presented as the mean and standard deviation (SD). Significant differences between groups were analyzed using the Tukey test with a significance level of $5 \%$. The data were analyzed using Sigmastat 3.5 software (Systat Software GmbH).

\section{RESULTS}

Significant treatment effect for the factors "intracanal medication" $(\mathrm{P}<0.001)$ and "evaluation time" ( $\mathrm{P}<0.001)$ and for the interaction between the two factors $(\mathrm{P}<0.001)$ were observed by Analysis of variance. Multiple comparisons were performed using Tukey test $(\alpha=0.05)$, and the results are shown in Table 2.

Based on the results, the cytotoxicity of the different groups were similar at 30 minutes and 12 hours time points (Figure 1). Within 24 hours, the CPG, IG and OT groups displayed different behaviors compared to the control group, demonstrating the lowest absorbance values at this time. At 48 hours, only the OT group, which had the lowest absorbance value, was different from the control group. At 72 hours, 5 days and 7 days, all groups showed different behaviors compared to the control group, and the OT group had the lowest absorbance value for this period. The cytotoxicity of all groups progressively differed from the control group as time passed, i.e., the absorbance values decreased as time increased. 
Table 2. Results of cytotoxicity in mean (SD) expressed in absorbance units.

\begin{tabular}{|c|c|c|c|c|c|c|c|}
\hline \multirow{2}{*}{$\begin{array}{l}\text { Intracanal } \\
\text { Medication }\end{array}$} & \multicolumn{7}{|c|}{ Evaluation time } \\
\hline & $\begin{array}{c}30 \\
\text { minutes }\end{array}$ & $\begin{array}{c}12 \\
\text { hours }\end{array}$ & $\begin{array}{c}24 \\
\text { hours }\end{array}$ & $\begin{array}{c}48 \\
\text { hours }\end{array}$ & $\begin{array}{c}72 \\
\text { hours }\end{array}$ & $\begin{array}{c}5 \\
\text { days }\end{array}$ & $\begin{array}{c}7 \\
\text { days }\end{array}$ \\
\hline \multirow{3}{*}{ CPG } & 1.07 & 1.08 & 0.91 & 1.06 & 0.93 & 0.56 & 0.47 \\
\hline & $(0.21)$ & $(0.14)$ & $(0.08)$ & $(0.08)$ & $(0.11)$ & $(0.10)$ & $(0.21)$ \\
\hline & $\mathrm{Aa}$ & $\mathrm{Aa}$ & $\mathrm{ABb}$ & $\mathrm{Aa}$ & $\mathrm{ABb}$ & $\mathrm{Bc}$ & $\mathrm{Bc}$ \\
\hline \multirow{3}{*}{ IG } & 1.18 & 1.09 & 0.81 & 1.08 & 0.91 & 0.67 & 0.49 \\
\hline & $(0.30)$ & $(0.10)$ & $(0.08)$ & $(0.14)$ & $(0.10)$ & $(0.12)$ & $(0.16)$ \\
\hline & $\mathrm{Aa}$ & $\mathrm{Aa}$ & $\mathrm{Bbc}$ & $\mathrm{Aa}$ & $\mathrm{ABb}$ & $\mathrm{ABcd}$ & $\mathrm{Bd}$ \\
\hline \multirow{3}{*}{ CIW } & 1.20 & 1.07 & 0.87 & 1.18 & 0.82 & 0.67 & 0.51 \\
\hline & $(0.19)$ & $(0.11)$ & $(0.07)$ & $(0.16)$ & $(0.12)$ & $(0.14)$ & $(0.10)$ \\
\hline & $\mathrm{Aa}$ & $\mathrm{Aa}$ & $\mathrm{Ab}$ & $\mathrm{Aa}$ & $\mathrm{ABbc}$ & $\mathrm{ABcd}$ & $\mathrm{ABd}$ \\
\hline \multirow{3}{*}{ IW } & 1.20 & 1.17 & 0.89 & 1.07 & 0.93 & 0.63 & 0.44 \\
\hline & $(0.17)$ & $(0.12)$ & $(0.07)$ & $(0.10)$ & $(0.10)$ & $(0.06)$ & $(0.11)$ \\
\hline & $\mathrm{Aa}$ & $\mathrm{Aa}$ & $\mathrm{Ab}$ & $\mathrm{Aa}$ & $\mathrm{ABb}$ & $\mathrm{ABc}$ & $\mathrm{Bc}$ \\
\hline \multirow{3}{*}{$\mathrm{CW}$} & 1.26 & 1.15 & 0.98 & 1.11 & 0.79 & 0.69 & 0.47 \\
\hline & $(0.22)$ & $(0.14)$ & $(0.11)$ & $(0.11)$ & $(0.13)$ & $(0.09)$ & $(0.07)$ \\
\hline & $\mathrm{Aa}$ & $\mathrm{Aa}$ & $\mathrm{Ab}$ & $\mathrm{Aa}$ & $\mathrm{Bc}$ & $\mathrm{ABd}$ & $\mathrm{Bd}$ \\
\hline \multirow{3}{*}{ OT } & 1.16 & 1.07 & 0.80 & 0.85 & 0.50 & 0.25 & 0.22 \\
\hline & $(0.10)$ & $(0.12)$ & $(0.03)$ & $(0.06)$ & $(0.16)$ & $(0.04)$ & (0.03) \\
\hline & $\mathrm{Aa}$ & $\mathrm{Aa}$ & $\mathrm{Bb}$ & $\mathrm{Bb}$ & $\mathrm{BCc}$ & $\mathrm{Cd}$ & $\mathrm{Cd}$ \\
\hline \multirow{3}{*}{ Control } & 1.14 & 1.07 & 1.00 & 1.19 & 0.95 & 0.77 & 0.65 \\
\hline & $(0.08)$ & $(0.11)$ & $(0.06)$ & $(0.14)$ & $(0.11)$ & $(0.21)$ & $(0.11)$ \\
\hline & $\mathrm{Aa}$ & $\mathrm{Aab}$ & $\mathrm{Ab}$ & $\mathrm{Aa}$ & $A c$ & $\mathrm{Ad}$ & $\mathrm{Ad}$ \\
\hline
\end{tabular}

Different letters (uppercase upright, tiny horizontal) indicate statistically significant difference $(\alpha=0.05)$.

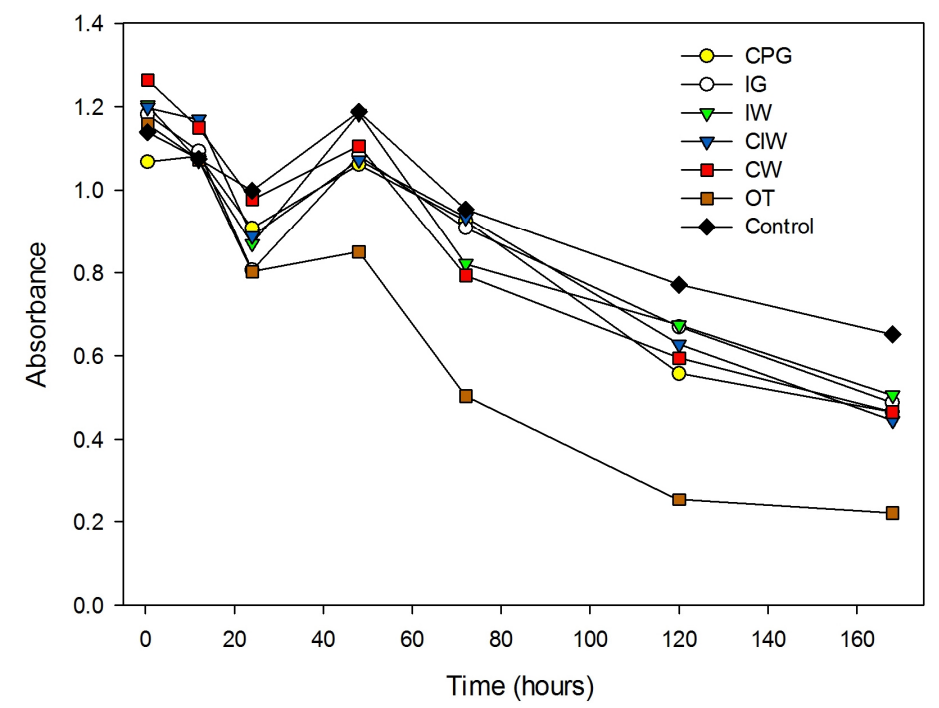

Figure 1. Absorbance values of the different groups at different periods of observation. 


\section{DISCUSSION}

Intracanal medications need to be biocompatible because they come into direct contact with periapical tissues during endodontic treatment. Otherwise, these medications can be cytotoxic, i.e., induce cell death. Because of the lack of cytotoxicity research in this area, this study aimed to determine the toxic effects of intracanal medications on fibroblasts.

When evaluating experimental design for cytotoxicity studies, cell type is an important factor for consideration. Some studies (CHANG et al., 1998; CAMARGO et al., 2009; SEPET et al., 2009; SILVA et al., 2012A; SILVA et al., 2012B; YOSHINO et al., 2013) used fibroblasts for quick and easy growth (HIRSHMAN et al., 2012), in addition to their availability in periapical tissues and the periodontal ligament, which are areas that are susceptible to the effects of intracanal medications and their degradation products (YOSHINO et al., 2013). Fibroblasts are also the largest producers of collagen tissue and, therefore, actively participate in the repair tissue process (SILVA et al., 2012B).

In this study, between the 30 minutes and 12 hours time points, there were no cytotoxic effects on L929 fibroblast cells from any of the groups. A greater contact period of intracanal medications with cells may be required in vitro, as longer experimental periods in this study were marked by reduced cell viability.

The results of this study show that time was an influencing factor in the viability of cells subjected to intracanal medications. This decreased viability was also observed in cells subjected to calcium hydroxide in studies by Guigand et al., 1999 and Sepet et al., 2009. The increase in cell death can be attributed to the duration of medication exposure and to the alkaline $\mathrm{pH}$ induced by all of the intracanal medications used in this study except Otosporin ${ }^{\circledR}$.

It should be emphasized that Otosporin ${ }^{\circledR}$ (OT) proved to be the most cytotoxic intracanal medication in this study. This toxicity was observed in studies conducted by Miura et al., 2010 at the highest concentration used. This cytotoxicity appears to be related to the presence of the antibiotic polymyxin B present in Otosporin ${ }^{\circledR}$, which acts directly on the cell membrane. Polymyxin B affects the osmotic properties and transport mechanisms of the cell membrane, leading to cell death. This action is not selective; polymyxin B also affects human cells due to similarities in membrane composition with bacteria (NEIVA et al., 2013). Another observation that seems to corroborate these results is the fact that the acidic environment induced by Otosporin ${ }^{\circledR}$ interferes with cell metabolism, which requires a neutral $\mathrm{pH}$ for normal function.

The second most cytotoxic intracanal medication in this study was the calcium hydroxide with distilled water $(\mathrm{CW})$. This finding is in agreement with previous studies, which have reported that this medication is very cytotoxic compared to various other endodontic materials (YASUDA et al., 2010; SILVA et al., 2012B). The rationale for the observed cytotoxicity may be the extremely alkaline environment, which promotes enzymatic denaturation and destruction of the cell membrane, leading to cell death (GUIGAND et al., 1999; SEPET et al., 2009; SILVA et al., 2012B). In animals, this cytotoxic action occurs when calcium hydroxide comes in direct contact with subcutaneous tissue, inducing inflammatory reactions of moderate to severe intensity and resulting in protein denaturation in the cells, especially of neutrophils, and areas of necrosis and dystrophic calcification (NELSON FILHO et al., 1999; CAMARGO et al., 2010; TOMAZ et al., 2013).

In this study, the intracanal medications with the highest cell viability, which were therefore the least cytotoxic to L929 fibroblasts, were CPG paste and Iodoform with distilled water (IW). The CPG paste was constituted with CPMC because free association with other substances has been shown to be extremely cytotoxic (CHANG et al., 1998; MIURA et al., 2010). Experimental studies in animal models have shown that, when CPMC is associated with calcium hydroxide and glycerin in CPG paste, this toxicity is reduced to levels compatible with tissues (GRECCA et al., 2001) and the paste shows no genotoxicity or mutagenicity (GAHYVA; SIQUEIRA JUNIOR, 2005).

The high cell viability demonstrated in this study upon administration of this paste can be credited to the small concentrations of CPMC released into the tissues. When combined with calcium hydroxide, CPMC produces a slightly soluble salt, calcium paramonochlorophenolate, which slowly releases paramonochlorophenol and $\mathrm{Ca}^{2+}$ and $\mathrm{OH}^{-}$ions into the medium, resulting in the absence of tissue toxicity (ANTHONY et al., 1982). Moreover, glycerin, a viscous vehicle, is present in this medication, allowing slow dissociation and diffusion of ions into the medium (VIANNA et al., 2009).

The other medication that produced low cytotoxicity in fibroblast cells was Iodoform with distilled water (IW). The low cytotoxicity of iodoform can be correlated with the type of 
inflammatory response it induces when exposed to the subcutaneous tissue of rats. Using histological sections from rats exposed to iodoform, a number of studies have shown a small area of necrosis restricted to the wound area, surrounded by little inflammatory infiltrate, confirming a mild inflammatory reaction in the region followed by rapid tissue repair (CWIKLA et al., 2005; TOMAZ et al., 2013).

These results should be taken into consideration because cultured cells in vitro are considered to be more sensitive than cells in vivo because they live in a dynamic environment, reducing their susceptibility to death. Thus, further testing in vitro and in vivo is required to determine the long-term biocompatibility of different combinations of intracanal medications with periradicular tissue for continued safety in endodontic therapy.

\section{CONCLUSIONS}

The present study showed that time was an influencing factor in reducing the cell viability of all intracanal medications.

The intracanal medication Otosporin ${ }^{\circledR}(\mathrm{OT})$ was the most cytotoxic to L929 fibroblast cells, and the calcium hydroxide with distilled water $(\mathrm{CW})$ was the second most cytotoxic.

The medications CPG and Iodoform with distilled water (IW) were endodontic pastes that allowed greater cell viability in fibroblasts and, therefore, were less cytotoxic in this study.

Showing the cytotoxicity of intracanal medications suggests your statement with caution in endodontic therapy, since the drugs act not only against microorganisms as well as in cells of the periradicular tissues.

RESUMO: Este estudo teve como objetivo avaliar a citotoxicidade de medicações intracanais em células L929 de fibroblastos em diferentes períodos de observação. Os seguintes grupos experimentais foram estudados: hidróxido de cálcio com paramonoclorofenol canforado e glicerina (CPG); iodofórmio com glicerina (IG); hidróxido de cálcio com iodofórmio e água destilada (CIW); iodofórmio com água destilada (IW); hidróxido de cálcio com água destilada (CW); Otosporin $^{\circledR}$ (OT); e um grupo controle composto por células e meio de cultura. Os eluatos foram preparados a partir de cada grupo e colocados em contato com 1 x $10^{5}$ células/poço, por períodos de 30 minutos, 12, 24, 48 e 72 horas, 5 e 7 dias. Depois de cada período experimental, um teste de citotoxicidade foi realizado utilizando metiltetrazólio (MTT) e um espectrofotômetro a uma densidade óptica de $570 \mathrm{~nm}$ para analisar a viabilidade celular. A análise de variância e o teste de Tukey com nível de significância de 5\% foi utilizado para analisar os dados. Em 30 minutos e em 12 horas, todos os grupos foram iguais ao grupo controle. Em 24 horas, houve uma maior citotoxicidade no grupo IG do que no grupo controle $(\mathrm{P}<0,001)$. Em 48 horas, apenas o grupo OT foi citotóxico $(\mathrm{P}<0,001)$. Em 72 horas e em 5 dias, os grupos mais citotóxicos foram CW e OT. Aos 7 dias, os grupos IW e CPG foram os menos citotóxicos $(\mathrm{P}<0,001)$. Com relação ao tempo experimental, foram observadas diferenças significativas entre 24 horas e 7 dias em todos os grupos. Conclusão: Otosporin ${ }^{\circledR}$ foi o medicamento mais citotóxico, seguido de hidróxido de cálcio com água destilada.

PALAVRAS-CHAVE: Endodontia. Fibroblastos. Hidróxido de cálcio. Iodofórmio. Testes imunológicos de citotoxicidade

\section{REFERENCES}

ANTHONY, D. R.; GORDON, T. M.; DEL RIO, C. E. The effect of three vehicles on the pH of calcium hydroxide. Oral Surg Oral Med Oral Pathol. St. Louis, v. 54, n. 5, p. 560-5, 1982.

http://dx.doi.org/10.1016/0030-4220(82)90195-5

CAMARGO, S. E.; CAMARGO, C. H.; HILLER, K. A.; RODE, S. M.; SCHWEIKL, H.; SCHMALZ, G. Cytotoxicity and genotoxicity of pulp capping materials in two cell lines. Int Endod J. Oxford, v. 42, n. 3, p. 227-37, 2009. http://dx.doi.org/10.1111/j.1365-2591.2008.01506.x

CAMARGO, S. E.; RODE, S. M.; DO PRADO, R. F.; CARVALHO, Y. R.; CAMARGO, C. H. Subcutaneous tissue reaction to castor oil bean and calcium hydroxide in rats. J Appl Oral Sci. Bauru, v. 18, n. 3, p. 273-8, 2010. http://dx.doi.org/10.1590/S1678-77572010000300014 
CHANG, Y. C.; HUANG, F. M.; CHENG, M. H.; CHOU, L. S.; CHOU, M. Y. In vitro evaluation of the cytotoxicity and genotoxicity of root canal medicines on human pulp fibroblasts. J Endod. New York, v. 24, n. 9, p. 604-6, 1998. http://dx.doi.org/10.1016/S0099-2399(98)80119-2

CWIKLA, S. J.; BÉLANGER, M.; GIGUÈRE, S.; PROGULSKE-FOX, A.; VERTUCCI, F. J. Dentinal tubule disinfection using three calcium hydroxide formulations. J Endod. New York, v. 31, n. 1, p. 50-2, 2005. http://dx.doi.org/10.1097/01.DON.0000134291.03828.D1

ESTRELA, C.; ESTRELA, C. R. A.; GUIMARÃES, L. F.; SILVA, R. S.; PÉCORA, J. D. Surface tension of calcium hydroxide associated with different substances. J Appl Oral Sci. Bauru, v. 13, n. 2, p. 152-6, 2005. http://dx.doi.org/10.1590/S1678-77572005000200011

ESTRELA, C.; PESCE, H. F. Chemical analysis of the liberation of calcium and hydroxyl ions from calcium hydroxide pastes in connective tissue in the dog-Part I. Braz Dent J. Ribeirão Preto, v. 7, n. 1, p. 41-6, 1996.

GAHYVA, S. M. M.; SIQUEIRA JUNIOR, J. F. Direct genotoxicity and mutagenicity of endodontic substances and materials as evaluated by two prokaryotic test systems. J Appl Oral Sci. Bauru, v. 13, n. 4, p. 387-92, 2005. http://dx.doi.org/10.1590/S1678-77572005000400014

GOMES-FILHO, J. E.; WATANABE, S.; GOMES, A. C.; FARIA, M. D.; LODI, C. S.; OLIVEIRA, S. H. P. Evaluation of the effects of endodontic materials on fibroblast viability and cytokine production. $\mathbf{J}$ Endod. New York, v. 35, n. 11, p. 1577-9, 2009. http://dx.doi.org/10.1016/j.joen.2009.07.022

GRECCA, F. S.; LEONARDO, M. R.; DA SILVA, L. A.; TANOMARU FILHO, M.; BORGES, M. A. Radiografic evaluation of periradicular repair after endodontic treatment of dog's teeth with induced periradicular periodontitis. J Endod. New York, v. 27, n. 10, p. 610-2, 2001.

http://dx.doi.org/10.1097/00004770-200110000-00002

GUIGAND, M.; PELLEN-MUSSI, P.; LE GOFF, A.; VULCAIN, J. M.; BONNAURE-MALLET, M. Evaluation of the cytocompatibility of three endodontic materials. J Endod. New York, v. 25, n. 6, p. 419-23, 1999. http://dx.doi.org/10.1016/S0099-2399(99)80270-2

HEWARD, S.; SEDGLEY, C. Effects of intracanal mineral trioxide aggregate and calcium hydroxide during four weeks on $\mathrm{pH}$ changes in simulated root surface resorption defects: an in vitro study using matched pairs of human teeth. J Endod. New York, v. 37, n. 1, p. 40-4, 2011. http://dx.doi.org/10.1016/j.joen.2010.09.003

HIRSHMAN, W. R.; WHEATER, M. A.; BRINGAS, J. S.; HOEN, M. M. Cytotoxicity comparison of three current direct pulp-capping agents with a new bioceramic root repair putty. J Endod. New York, v. 38, n. 3, p. 385-8, 2012. http://dx.doi.org/10.1016/j.joen.2011.11.012

HOLLAND, R.; DE SOUZA, V.; NERY, M. J.; OTOBONI FILHO, J. A.; BERNABÉ, P. F. E.; DEZAN JÚNIOR, E. Reaction of rat connective tissue to implanted dentin tubes filled with mineral trioxide aggregate or calcium hydroxide. J Endod. New York, v. 25, n. 3, p. 161-6, 1999.

http://dx.doi.org/10.1016/S0099-2399(99)80134-4

HUANG, T. H.; HUNG, C. J.; CHEN, Y. J.; CHIEN, H. C.; KAO, C. T. Cytologic effects of primary tooth endodontic filling materials. J Dent Sci. Taiwan, v. 4, n. 1, p. 18-24, 2009.

http://dx.doi.org/10.1016/S1991-7902(09)60004-0

KANDASWAMY, D.; VENKATESHBABU, N.; GOGULNATH, D.; KINDO, A. J. Dentinal tubule disinfection with $2 \%$ chlorhexidine gel, propolis, morinda citrifolia juice, $2 \%$ povidone iodine, and calcium hydroxide. Int Endod J. Oxford, v. 43, n. 5, p. 419-23, 2010. http://dx.doi.org/10.1111/j.13652591.2010.01696.x 
LANA, P. E.; SCELZA, M. F.; SILVA, L. E.; MATTOS-GUARALDI, A. L.; HIRATA JÚNIOR, R. Antimicrobial activity of calcium hydroxide pastes on Enterococcus faecalis cultivated in root canal systems. Braz Dent J. Ribeirão Preto, v. 20, n. 1, p. 32-6, 2009. http://dx.doi.org/10.1590/S0103-64402009000100005

MATOS, F. S.; SOARES, A. F.; ALBUQUERQUE JÚNIOR, R. L. C.; RIBEIRO, S. O.; LIMA, G. D. N.; NOVAIS, S. M. A.; RIBEIRO, M. A. G. Effect of laser therapy on the inflammatory response induced by endodontic medications implanted into the subcutaneous tissue of rats. Rev Odontol UNESP. Araraquara, v. 43, n. 5, p. 343-50, 2014. http://dx.doi.org/10.1590/rou.2014.055

MIURA, C. A. S.; SÁ, M. S.; LIMA, R. S.; MACHADO, M. A. A. M.; TELLES, P. D. S. Avaliação da toxicidade de materiais endodônticos em células-tronco da polpa dentária. Rev Odontol Bras Central. Goiânia, v. 19, n. 50, p. 192-5, 2010.

MOSMANN, T. Rapid colorimetric assay for cellular growth and survival: application to proliferation and cytotoxicity assays. J Immunol Methods. Amsterdam, v. 65, n. 1-2, p. 55-63, 1983.

http://dx.doi.org/10.1016/0022-1759(83)90303-4

NEIVA, L. B. M.; DA FONSECA, C. D.; WATANABE, M.; VATTIMO, M. F. F. Polymyxin B: dose and time dependent nephrotoxicity effect in vitro. Acta Paul Enferm. São Paulo, v. 26, n. 1, p. 57-62, 2013. http://dx.doi.org/10.1590/S0103-21002013000100010

NELSON FILHO, P.; SILVA, L. A.; LEONARDO, M. R.; UTRILLA, L. S.; FIGUEIREDO, F. Connective tissue responses to calcium hydroxide-based root canal medicaments. Int Endod J. Oxford, v. 32, n. 4, p. 30311, 1999. http://dx.doi.org/10.1046/j.1365-2591.1999.00225.x

PALLOTTA, R. C.; MACHADO, M. E. L.; REIS, N. S.; MARTINS, G. H. R.; NABESHIMA, C. K. Tissue inflammatory response to implantation of calcium hydroxide and iodoform in the back of rats. Rev Odont Cienc. Porto Alegre, v. 25, n. 1, p. 59-64, 2010. http://dx.doi.org/10.1590/S1980-65232010000100012

SEPET, E.; PINAR, A.; ILHAN, B.; ULUKAPI, I.; BILIR, A.; TUNA, S. Cytotoxic effects of calcium hydroxide and mineral trioxide aggregate on 3T3 fibroblast cell line in vitro. Quintessence Int. Berlin, v. 40, n. 8, p. e55-61, 2009.

SILVA, E. J.; ACCORSI-MENDONÇA, T.; ALMEIDA, J. F.; FERRAZ, C. C.; GOMES, B. P.; ZAIA, A. A. Evaluation of cytotoxicity and up-regulation of gelatinases in human fibroblasts cells by four root canal sealers. Int Endod J. Oxford, v. 45, n. 1, p. 49-56, 2012A. http://dx.doi.org/10.1111/j.1365-2591.2011.01946.x

SILVA, E. J.; HERRERA, D. R.; ALMEIDA, J. F.; FERRAZ, C. C.; GOMES, B. P.; ZAIA, A. A. Evaluation of cytotoxicity and up-regulation of gelatinases in fibroblast cells by three root repair materials. Int Endod J. Oxford, v. 45, n. 9, p. 815-20, 2012B. http://dx.doi.org/10.1111/j.1365-2591.2012.02038.x

SILVA, E. J.; ROSA, T. P.; HERRERA, D. R.; JACINTO, R. C.; GOMES, B. P.; ZAIA, A. A. Evaluation of cytotoxicity and physicochemical properties of calcium silicate-based endodontic sealer MTA Fillapex. J Endod. New York, v. 39, n. 2, p. 274-7, 2013. http://dx.doi.org/10.1016/j.joen.2012.06.030

TOMAZ, P. J. S.; FARIAS, M. P.; PIVA, M. R.; ALBUQUERQUE JUNIOR, R. L. C.; RIBEIRO, M. A. G. Effect of laser therapy in inflamed tissue by medications based on iodoform laser therapy in inflamed tissue. Am J Appl Sci. New York, v. 10, n. 1, p. 81-8, 2013.

http://dx.doi.org/10.3844/ajassp.2013.81.88

VIANNA, M. E.; ZILIO, D. M.; FERRAZ, C. C.; ZAIA, A. A.; DE SOUZA-FILHO, F. J.; GOMES, B. P. Concentration of hydrogen ions in several calcium hydroxide pastes over different periods of time. Braz Dent J. Ribeirão Preto, v. 20, n. 5, p. 382-8, 2009. http://dx.doi.org/10.1590/S0103-64402009000500005 
YASUDA, Y.; TATEMATSU, Y.; FUJII, S.; MAEDA, H.; AKAMINE, A.; TORABINEJAD, M.; SAITO, T. Effect of MTAD on the differentiation of osteoblast-like cells. J Endod. New York, v. 36, n. 2, p. 260-3, 2010. http://dx.doi.org/10.1016/j.joen.2009.11.002

YOSHINO, P.; NISHIYAMA, C. K.; MODENA, K. C.; SANTOS, C. F.; SIPERT, C. R. In vitro cytotoxicity of White MTA, MTA Fillapex and Portland Cement on human periodontal ligament fibroblasts. Braz Dent J. Ribeirão Preto, v. 24, n. 2, p. 111-6, 2013. http://dx.doi.org/10.1590/0103-6440201302115 